\title{
RANCANG BANGUN WEB SERVICE SISTEM INFORMASI TERINTEGRASI GEREJA MASEHI INJILI DI MINAHASA (STUDI KASUS : GEREJA GMIM GETSEMANI LANSOT TOMOHON)
}

\author{
Yoshiko Tanaka Lumintang ${ }^{1)}$, Arie Lumenta ${ }^{2)}$, Oktavian Lantang ${ }^{3)}$ \\ ${ }^{1,2,3}$ Program Studi Teknik Informatika, Fakultas Teknik, Universitas Sam Ratulangi \\ Jl. Kampus UNSRAT Bahu, Manado, 95115 \\ Telp : (0431) 852959, Fax : (0431) 823705 \\ E-mail : 20yoshiko@gmail.com ${ }^{1)}$, arie.lumenta@gmail.com ${ }^{2)}$,oktavian_lantang@unsrat.ac.id ${ }^{3)}$
}

\begin{abstract}
Abstrak
Tujuan pembuatan Web Service Sistem Informasi Terintegrasi Gereja Masehi Injili di Minahasa adalah mrerancang dan membangun Web Service Sistem Informasi yang ada di Gereja Getsemani Lansot Tomohon, web service yang akan dibangun meliputi kontent RHK, MTPJ, Berita terbaru dan Warta Gereja. Sekarang ini sistem yang ada belum mencerminkan adanya integrasi antara kantor pusat dalam hal ini Sinode dan kantor wilayah maupun jemaat yang menggabungkan data menjadi satu di server dan bisa diakses dari satu tempat untuk mengetahui konten terbaru. Dengan memanfaatkan konsep Web Service diharapkan dapat meningkatkan kreatifitas dan kolaborasi antar pengguna Sistem Informasi Gereja. Web service mampu menggabungkan konten dari banyak penyedia layanan dan tergabung menjadi satu Sistem Terintegrasi untuk kemajuan Sistem Informasi Gereja.
\end{abstract}

Kata kunci: Web service, Sistem informasi, Terintegrasi, Gereja.

\section{PENDAHULUAN}

Sistem informasi Gereja berbasis web yang ada saat ini sebagian besar bersifat satu arah. Situs Gereja hanya menampilkan berita Gereja dengan konten yang hanya ditulis oleh administrator Gereja. Sistem yang ada belum mencerminkan adanya integrasi antara kantor pusat dalam hal ini Sinode dan kantor. Dengan memanfaatkan konsep web service diharapkan dapat meningkatkan kreatifitas dan kolaborasi antar pengguna sistem informasi Gereja. Web service mampu menggabungkan konten dari banyak penyedia layanan dan tergabung menjadi satu sistem terintegrasi untuk kemajuan sistem informasi Gereja.

\section{LANDASAN TEORI}

\subsection{Website}

Website atau lazim disingkat web adalah halaman informasi yang disediakan melalui jalur internet sehingga bisa diakses di seluruh dunia selama terkoneksi dengan jaringan internet. Web adalah salah satu alat komunikasi online yang menggunakan media internet dalam pendistribusiannya. Apapun bahasanya, yang pasti kita semua setuju bahwa website merupakan kumpulan halaman yang menampilkan informasi data teks, data gambar diam atau gerak, data animasi, suara, video dan atau gabungan dari semuanya, baik yang bersifat statis maupun dinamis yang membentuk satu rangkaian bangunan yang saling terkait dimana masing-masing dihubungkan dengan jaringan-jaringan halaman (hyperlink).

\subsection{Web Service}

Web service dapat diartikan juga sebuah metode pertukaran data, tanpa memperhatikan dimana sebuah database ditanamkan, dibuat dalam bahasa apa sebuah aplikasi yang mengkonsumsi data, dan di platform apa sebuah data itu dikonsumsi. Web service mampu menunjang interoperabilitas. Sehingga web service mampu menjadi sebuah jembatan penghubung antara berbagai sistem yang ada.

Web service menyimpan dan melakukan pertukaran datanya dalam format XML, karenanya menjadi multi platform dalam hal accessibilitynya. Karena XML merupakan suatu format dokumen yang berbasis teks, maka web service memungkinkan berlangsungnya komunikasi antar aplikasi yang berbeda dengan platform yang berbeda pula dan dapat menghemat waktu dalam komunikasi antara aplikasi dengan service penyedia. 


\subsection{Metode Waterfall}

Menurut Roger S. Pressman metode waterfall adalah model klasik yang bersifat sistematis, berurutan dalam membangun software.

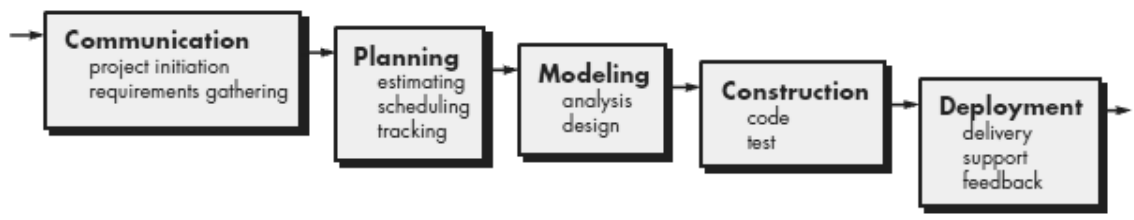

Gambar 1. Metode Waterfall

\section{METODOLOGI PENETILIAN}

\subsection{Kerangka Pikir}

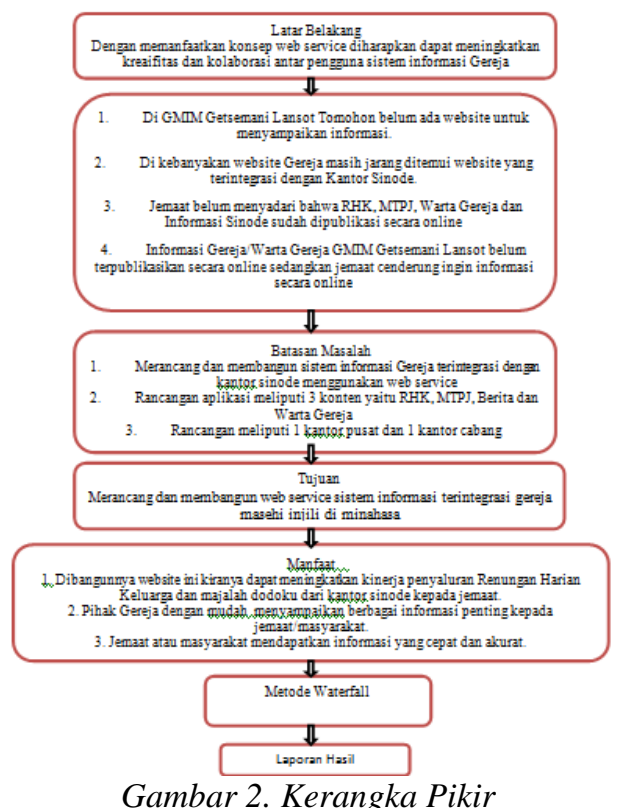

3.2 Tahap Pembuatan Perangkat Lunak

Rancang bangun web service sistem informasi terintegrasi gereja masehi injili di minahasa dilakukan dengan menggunakan metodologi Waterfall, tahapan Waterfall sendiri adalah sebagai berikut:

- Komunikasi

Sebelum spesifikasi-spesifikasi kebutuhan pengguna dapat dianalisis, dimodelkan, atau dispesifikasikan, mereka harus diperoleh melalui aktivitas-aktivitas komunikasi yang baik. Dalam hal ini, peneliti berkomunikasi dengan pegawai Gereja.

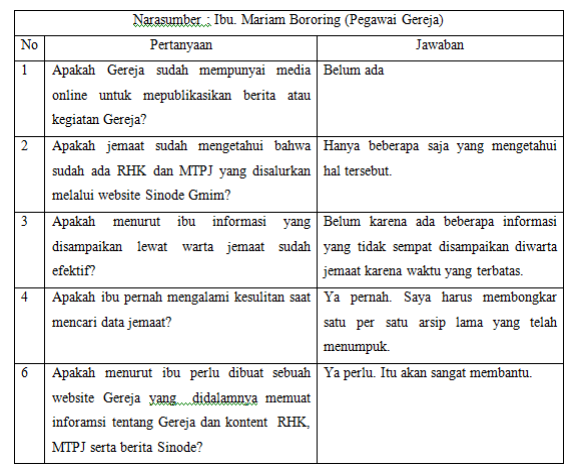

Tabel 1. Hasil Wawancara

- Perencanaan

Aktivitas perencanaan sesungguhnya merupakan sejumlah praktik manajemen dan teknis yang memungkinkan peneliti untuk mendefinisikan suatu peta jalan yang pada gilirannya memungkinkan peneliti 
mencapai tujuan-tujuan yang bersifat strategic dan taktis. Rencana yang sudah disusun oleh peneliti adalah sebagai berikut :

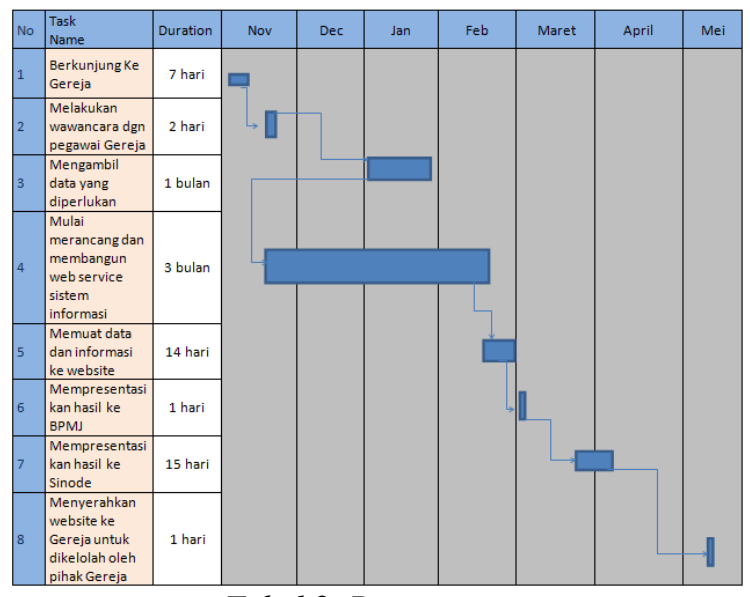

- Pemodelan

Tabel 2. Perencanaan

Kita membuat model-model untuk mendapatkan pemahaman yang lebih baik tentang entitas nyata yang akna dikembangkan.

1. Use case Diagram

Dalam Use case ini admin dapat mengelolah informasi yang ada seperti data jemaat, beranda, tentang Gereja, organisasi, galeri, warta jemaat kontak dan melihat komentar tapi admin tidak bisa mengelolah informasi dari RHK, MTPJ, Berita dan Warta Gereja yang merupakan kontent dari Sinode Gmim. Dalam Use case ini user dapat melihat semua informasi yang ditampilkan oleh admin dan user dapat mengirim komentar.

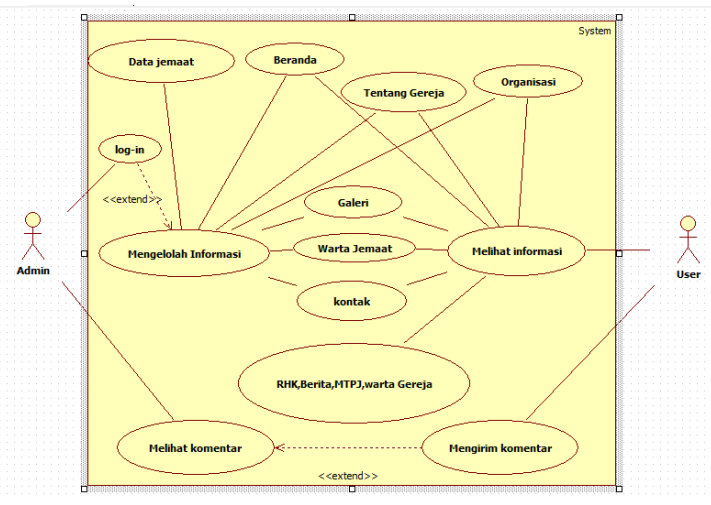

Gambar 3. Use case

2. Use case Description

Dalam Use case description mengelolah informasi, admin memilki hak penuh untuk menambah, menghapus atau mengedit informasi yang akan ditampilkan

\begin{tabular}{|l|l|}
\hline Nama usecase & Mengelolah Informasi \\
\hline Aktor & Admin \\
\hline Deskripsi & $\begin{array}{l}\text { Menambah, menghapus atau mengedit } \\
\text { informasi }\end{array}$ \\
\hline Normal course & $\begin{array}{l}\text { Admin mengelolah informasi untuk siap } \\
\text { ditampilkan }\end{array}$ \\
\hline Altemative course & - \\
\hline Pre-condition & Membuat informasi \\
\hline Post-condition & Menampilkan informasi \\
\hline Assumption & - \\
\hline
\end{tabular}

Tabel 3. Use case Description Mengolah informasi 


\section{Diagram Swimlane}

Diagram swimlane UML merupakan variasi yang bermanafaat untuk diagram aktivitas dan memungkinkan kita untuk memperlihatkan aliran aktivitas-aktivitas yang di deskripsikan oleh usecase dan pada saat bersamaan memperlihatkan aktor mana atau kelas analisis mana yang bertanggung jawab untuk aksi tertentu yang dideskripsikan oleh kotak aktivitas.

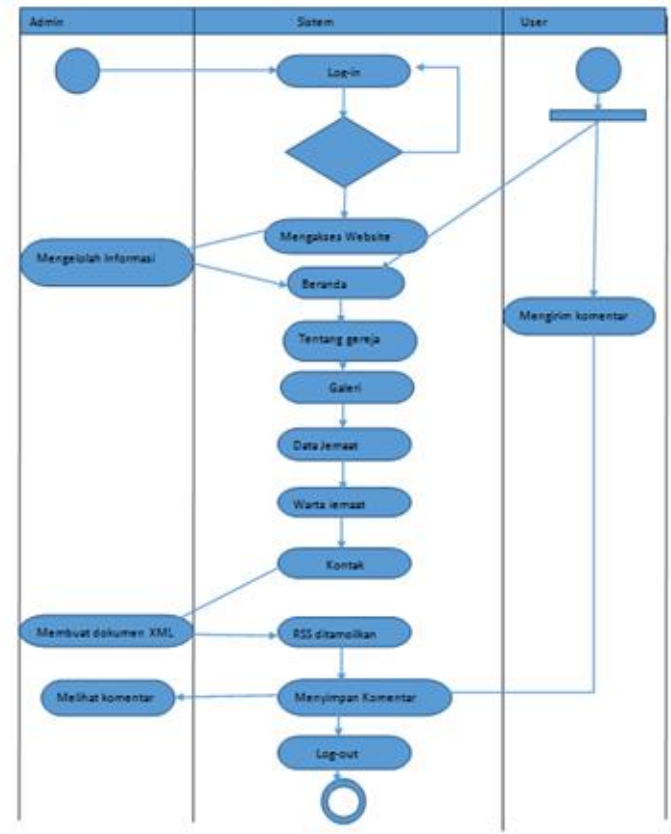

Gambar 4. Diagram Swimlane

- Kontruksi

Pada tahap ini dilakukan perancangan kode sumber. Berikut adalah rancangan sistem aplikasi yang dibangun beserta dengan hasil dari aplikasi.

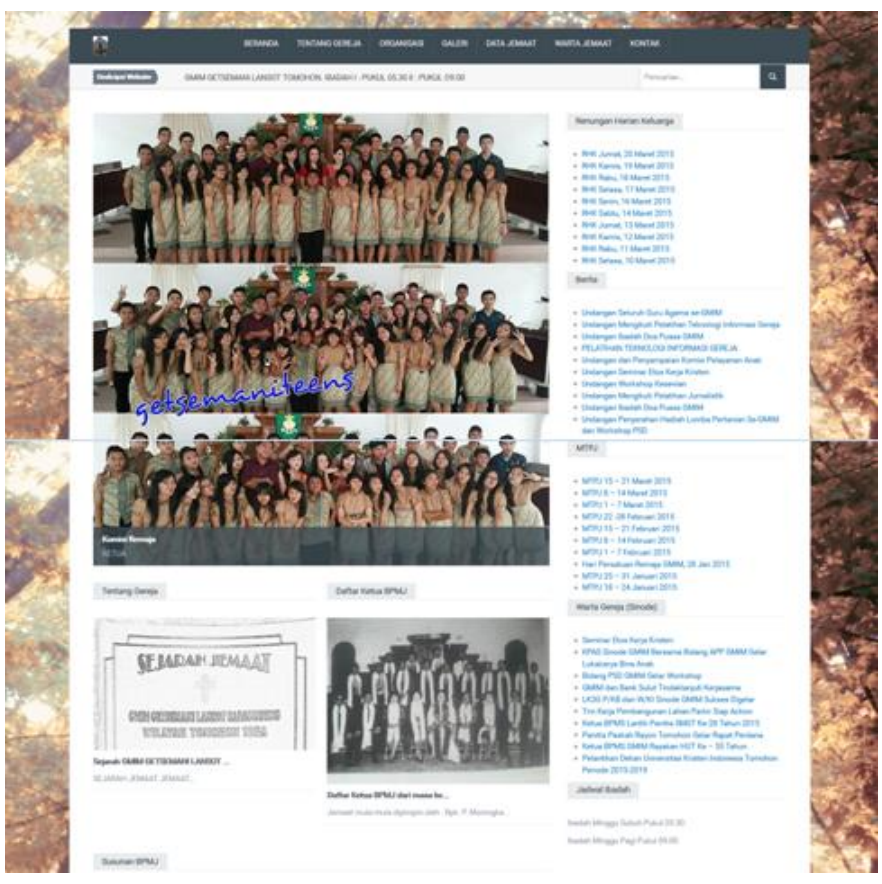

Gambar 5. Tampilan Beranda 


\section{HASIL DAN PEMBAHASAN}

Pada pembagian ini, penulis akan menampilkan hasil dari aplikasi yang telah dibuat serta pembahasannya.

\subsection{Beranda}

Dalam halaman beranda menampilkan semua fitur yang dapat diakses oleh user yaitu :

a) Tentang Gereja, yang memilki sub-menu berupa Sejarah dan Daftar Ketua BPMJ.

b) Organisasi, yang memiliki sub-menu berupa informasi dari PKB (Pria Kaum Bapa), WKI (Wanita Kaum Ibu), Pemuda, Remaja, ASM (Anak Sekolah Minggu) dan Susunan BPMJ.

c) Galeri, Fitur ini mencakup beberapa gambar yang menjadi kegiatan jemaat

d) Data jemaat, Fitur ini merupakan aplikasi yang dibangun oleh dua teman saya saat melakukan Kerja Praktek di Gereja GMIM Getsemani Lansot yang fungsinya untuk mendata jemaat sesuai form yang ada.

e) Warta Jemaat, Fitur ini mencakup informasi dari warta jemaat yang biasanya dibacakan saat selesai ibadah.

f) Kontak, Fitur ini mencakup informasi alamat dan nomor telepon Gereja

Donasi, Fitur ini mencakup informasi nomor rekening Gereja.

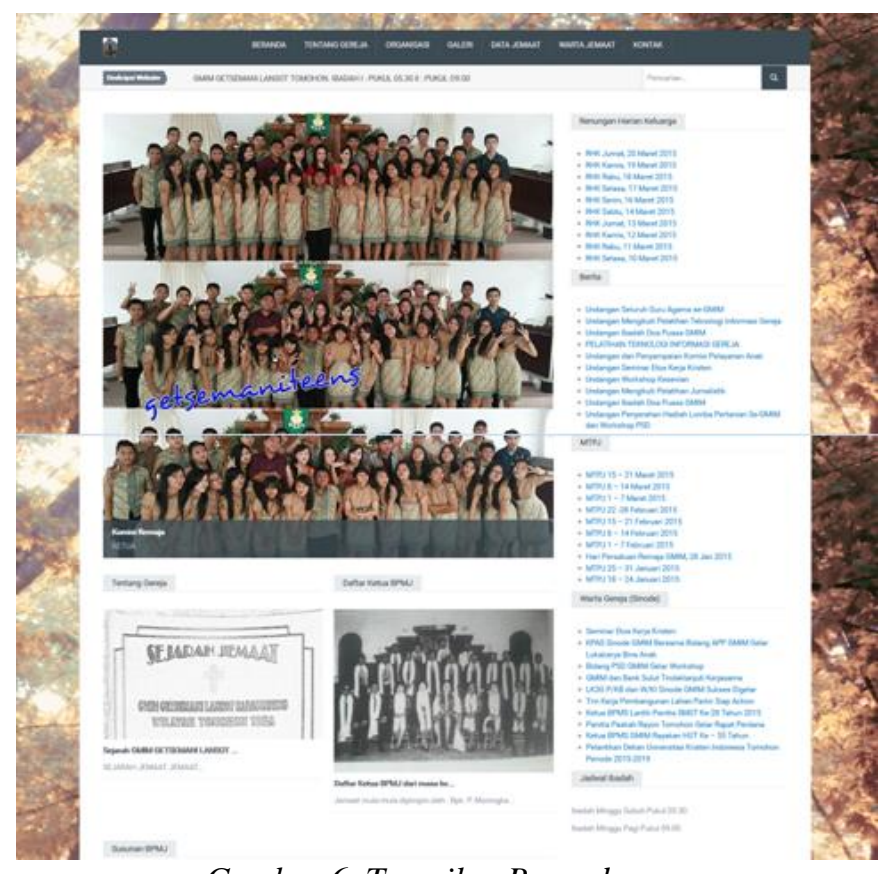

Gambar 6. Tampilan Beranda

\subsection{Data Jemaat}

Fitur ini merupakan aplikasi yang dibangun oleh dua teman saya saat melakukan Kerja Praktek di Gereja GMIM Getsemani Lansot yang fungsinya untuk mendata jemaat sesuai form yang ada.
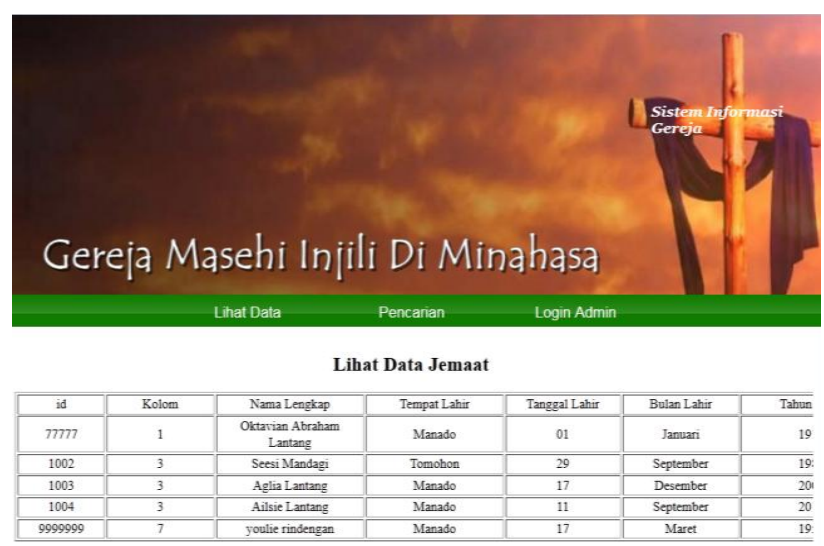

Gambar 7. Data Jemaat 


\section{PENUTUP}

\subsection{Kesimpulan}

Berdasarkan penelitihan yang telah dilakukan, maka dapat disimpulkan bahwa web service menjadi solusi untuk permasalahan yang dihadapi dalam hal integrasi. Dengan adanya web service, konten berupa RHK, MTPJ, Berita dan Warta Gereja dapat tersebar melalui website Gereja ke jemaat khususnya jemaat GMIM GETSEMANI LANSOT TOMOHON.

\subsection{Saran}

Apabila aplikasi ini akan dikembangkan, sebaiknya ditambakan konten-konten terbaru dari website resmi sinode GMIM agar memudahkan jemaat mendapat informasi yang lengkap, akurat dan cepat

\section{DAFTAR RUJUKAN}

[1] Abdilah,Tajuddin. 2012 "Rancang Bangun Manajemen Transaksi Berbasis Web Service Untuk Database Terdistribusi (studi kasus: Sistem Musrenbang Pada Kantor Desa Bulila Kecamatan Telaga) ”. Konferensi Nasional Sistem Informasi.

[2] D. Kakunsi. 2014 "Rancang Bangun Web Services Pada Aplikasi Presensi Pemerintah Kota Manado", Konferensi Nasional Sistem Informasi.

[3] http://www.gmim.or.id Renungan Harian Keluarga. http://www.gmim.or.id/read/rhk

12 Maret 2015

[4] http://www.popojicms.org popojicms. http://www.popojicms.org

10 November 2014

[5] Kasaedja, Bramwell. 2014 "Rancang Bangun Web Service Perpustakaan Universitas Sam Ratulangi". Konferensi Nasional Sistem Informasi.

[6] Pressman, S, Roger, Ph.D. 2010. "Rekayasa Perangkat Lunak Pendekatan Praktisi Edisi 7 (Buku 1)". Andi. Yogyakarta. 